\title{
FORECASTING THE FUTURE OF RELIGION IN THE 1920s: RAMSDEN BALMFORTH'S POST-ORTHODOX PROGNOSTICATIONS
}

\author{
Frederick Hale \\ North-West University
}

fh243@cam.ac.uk

\section{ABSTRACT}

Standing at the apogee of post-Protestant theological liberalism, the scholarly Unitarian minister Ramsden Balmforth, who served the Unitarian Church in Cape Town from 1897 until 1937, responded to a broad spectrum of issues affecting South African religious, political and economic life. Having been moulded by Fabian socialism in his native Yorkshire, however, and informed by the theology of such denominational fellows as Joseph Estlin Carpenter during his student years in Oxford, he remained relatively marginalised on the ecclesiastical landscape of South Africa. Despite this quasi-isolation, Balmforth sought in the late 1920s to predict the future of Christianity or religious life generally not only in his adopted homeland, but also on an international scale. In the present article his conceptualisation is analysed in the historical context of his theological liberalism generally, and a critique of his prognostications is offered which highlights Balmforth's failure to come to grips with the fact that his liberalism, which he regarded as a virtually inevitable product of cultural history, had failed to make nearly any inroads on the increasingly complex kaleidoscope of South African Christianity.

\section{INTRODUCTION}

What did the future of Christianity - and, by extension, of formal religious life generally - look like in the Union of South Africa during the tumultuous 1920s? Both at home and abroad that decade was a watershed era of significant theological and ecclesiastical strife, a time of rapid change as competing religious views vied

\section{UNISA $\cong$}


for position. On the South African Christian landscape, urbanisation continued apace, as migrants from nearly all ethnic groups swelled industrial areas, and, in response to this demographic shift, more emphasis was placed on urban missionary endeavours. Simultaneously, the ever-mutating kaleidoscope of African independent churches became more complex. Within Dutch Reformed circles, especially the Nederduitse Gereformeerde Kerk, the debate surrounding Professor Johannes du Plessis of Stellenbosch called attention to the presence - and alleged proliferation - of theological inconsistency in that denomination. Pentecostal movements emanating from the United States of America and elsewhere continued to expand, bringing renewed emphasis on gifts of the Holy Spirit to the liturgical life of churches. These and other noteworthy developments, all of which have been the subject of considerable research, underscored both the diversity and the discord of South African Christianity early in the twentieth century. It all pointed to ongoing fracturing of the body of Christ in later decades, which, to be sure, also included many noteworthy instances of ecclesiastical mergers, comity arrangements on the mission field, and other forms of co-operation. But to any reasonably keen-eyed observer with even a moderate degree of theological sophistication, the centrifugal tendencies could hardly be ignored.

Not all agreed with such an assessment. Viewing the trajectory of recent church history from a unique perspective, and with his perception unabashedly filtered by his own post-orthodox theological presuppositions and an unswerving commitment to Darwinian evolutionary thought, the Unitarian minister Ramsden Balmforth of Cape Town issued a radically different prognosis. Writing in 1929, 32 years after his arrival in South Africa, he asserted with no mean degree of certainty that denominational distinctives were already waning and extrapolated that 'the religion of the future' would thus be a 'modernist' synthesis of universally shared ethical values and a progressive understanding of social harmony which encouraged people to develop their human potential.

Read nearly a century later, his optimism boggles the mind. Nevertheless, for all its naïveté, Balmforth's forecast merits scholarly consideration as a historical phenomenon. He was arguably one of the most erudite men of the cloth in South Africa and also one of its most prolific with the pen. Having studied theology in Oxford almost immediately before sailing to the Cape, Balmforth maintained close ties with liberal theology in his native land. He also continued to write about literary, cultural, and political developments in the United Kingdom and continental Europe. To be sure, it is difficult to gauge the extent to which he influenced religious thought outside Cape Town, where he was not only the minister of a relatively small but erudite flock of liberally minded English- and Afrikaans-speaking burghers, but also a well-known and civic-minded resident who served on various kinds of committees and contributed a seemingly endless series of letters and essays to the local press. To cite but a handful of his public responsibilities, in 1927, 30 years after his arrival in Cape Town, Balmforth was simultaneously 'a member of the Cape Division School 
Board, the Cape Town Juvenile Affairs Board, Vice-president of the South African Peace Society, and a member of the executive committee of the Cape Town League of Nations Union'. ${ }^{1}$ After his death in 1941, editor John Cope of the Johannesburg weekly, The Forum, professed that 'Ramsden Balmforth will long be remembered in Cape Town and, indeed, in South Africa, as a pioneer of progressive thought.'2 On the other hand, reasons underlying the limits of his vision regarding the present and projected state of religious life highlight the blinkers that even a man of his intelligence had with regard to inter alia new developments in Christian (and, for that matter, non-Christian) spirituality in several parts of the country and, not least, the transformation of religious life among its peoples whose ancestral roots did not lie in Europe.

The present article analyses Balmforth's (1929c) Modernism and the religion of the future in its historical context. This will entail first sketching the English theological (and to a considerable degree anti-theological) and ideological milieu in which he was raised and spent his early adulthood, dissecting an essay about 'The future development of religious life' which he penned before undertaking studies for the Unitarian ministry, describing certain pivotal currents of intellectual life which were flowing swiftly in Oxford during his years there in the 1890s, and considering his relationship to other religious groups in Cape Town between his arrival there in 1897 and the publication of the main article under review 32 years later.

It will be argued that despite his erudition, international perspectives, and seemingly inclusive view of religious life, Balmforth in fact lacked significant exposure to and meaningful appreciation of most theological stances other than his own. In this respect, he was actually rather narrow-gauged in his religious views. This tunnel vision prevented him from having nearly as adequate a comprehension of the contemporary course of religion to perceive how much of it ran counter to his certitude that especially Christian denominations were well on their way to sloughing off their distinctive characteristics and melding together in broad, ecumenical harmony guided by modernist theology.

\section{A TRANSPLANTED YORKSHIRE UNITARIAN AND FABIAN SOCIALIST}

Born in the Yorkshire industrial city of Huddersfield in 1861, Balmforth emigrated to Cape Town when he was 36 years old and, apart from infrequent return visits to England and at least one trip to South Asia, remained in that city until his death more than four decades later. Despite his very active participation in the religious, educational, political and cultural life of South Africa, he never severed his umbilical cord to British intellectual and cultural life. When one reads his many

1 'Cape Town Jubilee', The Inquirer, no. 4,435, 2 July 1927, Supplement, p. ii.

2 'Intrepid liberal' (editorial), The Forum, IV(41), 10 January 1942, p. 5. 
books and other publications, one can hardly fail to notice the ongoing influence of the liberal theology which he had imbibed in the late Victorian period. Overcoming early secularist antipathy to religion generally, Balmforth came under the sway of Unitarianism in his twenties, and at no subsequent point does he appear to have seriously questioned that tradition's modernist emphases. He remained firmly in its grasp for the rest of his days.

Of equally great importance in the early unfolding of his Weltanschauung was the young socialist movement in the United Kingdom. In 1890 Balmforth joined the Fabian Society, which had been founded in London seven years earlier and sought to promote evolutionary socialism in the United Kingdom. He remained a life-long member, ${ }^{3}$ and both his socialistic views and his admiration of the most renowned Fabian, George Bernard Shaw, exercised a profound influence on his writing and other activities. Balmforth's commitment to the gradualist, or 'evolutionary', socialist reform agenda which the Fabian Society advocated dovetailed neatly with his overarching and deeply rooted understanding of evolution as an underlying principle of history. He was, in short, a political and economic progressive, not a revolutionary.

\section{VICTORIAN SECULARIST ROOTS}

Balmforth's prognostications about the future of religion in the twentieth century were inextricably tied to his upbringing in nineteenth-century England. By his own account, he was raised in a non-religious family. Atheism had become a fairly visible public phenomenon in England by the mid-Victorian period, not least in workingclass areas of industrial cities. ${ }^{4}$ Writing late in life, the future Unitarian minister recalled that unlike many churchgoing children in Huddersfield, he and his siblings attended a Sunday school sponsored by the National Secular Society, a young and vibrant organisation founded in 1866 chiefly by the increasingly prominent atheist Charles Bradlaugh ${ }^{5}$ and such associates as George Holyoake and Charles Watts in 1866 as an amalgamation of existing but considerably smaller bodies in the United Kingdom. ${ }^{6}$ Balmforth remembered the curriculum as having included 'reading,

3 Sue Donnelly (Archives, London School of Economics) to Frederick Hale, 17 September 2012 (electronic correspondence).

4 The proliferation of atheism in the United Kingdom since the seventeenth century is delineated in D. Berman. 1990. A history of atheism in Britain: From Hobbes to Russell. London: Routledge.

5 Niblett, B. 2011. Dare to stand alone: The story of Charles Bradlaugh. Oxford: Kramedart Press, is the most recent of several biographies.

6 Particularly useful for the general history of secularism, are E. Royle, 1974. Victorian infidels: The origins of the British Secularist Movement, 1791-1866. Manchester University Press; and E. Royle, 1980. Radicals, secularists and republicans: Popular Freethought in Britain, 1866-1915. Manchester University Press. 
writing, singing, and a little history instead of Bible lessons'. He and his fellow young secularists were 'often' described as attending an 'infidel' school. The young Balmforth was exposed to Christianity at the primary school which he attended during the week, and when he was eventually appointed as the Unitarian minister in his hometown the Congregationalist headmaster of that school attended at least one of his services. ${ }^{7}$ However, his formal childhood education ended when he was only 11 years old, and there is no evidence that he had noteworthy exposure to organised religious life during his subsequent years as an employee of the very secular and socialist Huddersfield Cooperative Stores, in whose employ Balmforth remained until his late twenties.

His intellectual formation within the Secular Society continued for several years. At its meetings, Balmforth thus heard lectures delivered not only by Bradlaugh, Watt, and Holyoake, but also J.M. Robertson, G.W. Foot, Edward Aveling, Torzean Parris, Harriet Law and Annie Besant. The topics which these 'leading Freethought writers and speakers in England' chose were drawn from 'political, social, ethical, religious, and abstruse philosophical subjects' ${ }^{8}$ Ideologically, these luminaries of the Left were not a uniform lot; Bradlaugh, for example, was notoriously unwilling to sacrifice individualism on the altar of socialism. In any case, Balmforth left no evidence of input from Tory thinkers or Trinitarian Christians prior to his twenties. For many years while a teenager and in his twenties, he read extensively, but the emphases in his publications, which began to appear in the late 1880s, suggest that he was still preoccupied with post-orthodox religious views in addition to Victorian socialism. At no point did Balmforth evince significant understanding of any forms of Christian theology other than those which, broadly speaking, can be characterised as Unitarian or otherwise very liberal.

\section{BALMFORTH'S EARLIEST SPECULATION ABOUT POST-CHRISTIAN RELIGION}

The first non-fictional piece Balmforth is known to have published about religion, one which clearly foresaged his prognosis of 1929, was a two-part essay he contributed to The Westminster Review in 1889. He was then 28 years old, still employed at the Huddersfield Industrial Society, and in the autodidactic phase of his education. In his treatise, ambitiously titled 'The future development of religious life', Balmforth, writing under the pseudonym 'Laon Ramsey' (1889), implicitly underscored both his autonomy from traditional theological conventions and his indebtedness to certain nineteenth-century intellectual currents.

7 Bridget Stoddart private archives, Fish Hoek, Ramsden Balmforth handwritten memoirs, (n.d.), pp. 12-13.

8 Balmforth (n.d.), unpublished memoirs, p. 14. 
The swiftest of the latter was, apparently, evolutionary thought. Balmforth (Ramsey 1889) agreed wholeheartedly with a recently expressed view of the Germanborn and educated philologist and Orientalist Friedrich Max Müller (1823-1900) that every religion is susceptible to 'inevitable decay'. One of the principal founders of comparative religion as an academic discipline, and the man who introduced it to the British public during his many years as a professor at the University of Oxford during the 1860s and 1870s (not least through his four-volume Chips from a German Workshop [1867-1875]), Müller was clearly a scholar from whom Balmforth apparently took many of his cues. To the young socialist, this German's generalisation about the impermanence of religions harmonised with his observation that all matter was in a state of 'perpetual transformation', and it also resonated with his own observations of variegated Christianity in England, where 'religious life, in all its forms and aspects, is subject to the law of evolution.' Rejecting the prejudice of orthodox Christians that their religion was immutable and everlasting, he pointed out that since the time of Jesus, Christianity had evolved through numerous stages, inter alia 'the Galilean era', the apostolic church, the time of Gnosticism, 'Ecclesiasticism' or Roman Catholicism, and the post-Reformation centuries of 'Protestantism and its off-shoots'. In his own time, Balmforth (Ramsey 1889) could point to 'a tendency to broaden theological doctrine' and illustrated this with liberal fruits of Biblical and theological scholarship, especially a wide rejection of literalistic hermeneutics which apparently was making Christianity more palatable to his sceptical mind. He was clearly relieved that 'the doctrine of eternal torment, once vehemently upheld as a restraint on evil-doing, is now generally discredited'. How perceptive an observer he was of English Christianity, however, is questionable. He optimistically asserted: 'Even the most intolerant sections of the Church [of England] are influenced, perhaps unconsciously, by the liberal spirit of the age. ${ }^{9}$ No evidence to support this assertion was adduced.

In Balmforth's progressive view of the history of Christianity as expounded in 1889 , however, inhered a fundamental contradiction when viewed in the context of his own subsequent theological development. He insisted that there was 'a progressive continuity in the religious instinct and the religious life' and believed that Christianity was no exception to this general evolutionary law. Yet he had to concede that while the human spirit tended to strive ever higher for greater freedom and insight in spiritual matters, during the Middle Ages, Roman Catholicism (the major manifestation of Christianity at that time) had represented a retrogressive phenomenon in this regard. Balmforth (Ramsey 1889) sought to explain this away as an aberration, little more than a temporary setback in a longer, generally upward movement. 'Development is an absolute necessity,' he postulated. 'If then, there is a progressive continuity in religious instinct and religious life, it necessarily follows

9 Ramsey, L. 1889. 'The future development of religious life. Part I', The Westminster Review, CXXXI(6), May 1889, pp. 545-546. 
that on the decline of Christianity the religious life would still continue to manifest itself in other and superior forms.' However naïve and myopic this perception and reasoning are, and however obviously large numbers of post-Reformation and nineteenth-century religious developments flew in the face of Balmforth's socialist views of egalitarianism and social ethics, especially when one considers the phenomenon of religion globally, it fails to account for what he would subsequently argue in numerous publications was the essential, moral core of Christianity being eclipsed by layers of theology, which to his own mind implied the wholesale corruption and virtual destruction of that original faith.

In any case, Balmforth (Ramsey 1889) was not in doubt that what he termed (but did not define) 'orthodox Christianity' was in a state of 'decadence' hastened by 'the disintegrating tendencies of modern thought on orthodox beliefs'. But the inevitable mortality of the Christian religion was no reason for hopelessness, he explained. Following what had become axiomatic among scholars of comparative religion during the late nineteenth century, Balmforth, operating on the assumption that at its best religion was essentially a matter of 'striving after something higher' and of bestowing principles of moral conduct (rather than, for example, salvation through the death and resurrection of Jesus Christ), assured readers that other spiritual traditions, such as Hinduism, Buddhism, and 'Mohammedanism', offered much the same fare as Christianity. He quoted passages from the Koran, the Rig-veda, and other holy books of Asian religions to bolster this affirmation. Furthermore, to Balmforth the ethical fruits of these other faiths were incontrovertible and thus proved his point. 'This similarity, which is so apparent in a general view of the religions of the world, also manifests itself in the lives of the best of the adherents of each religion,' he generalised. 'Sakya-Muni, in the purity, devotion, and renunciation of his life, is, like Jesus, typical of sublime saintliness....' ${ }^{10}$

Furthermore, foreshadowing his subsequent spiritual development, Balmforth (Ramsey 1889) posited that religion, as 'a striving after something higher' ('God,' 'Nature,' 'The Unknowable, 'The beyond, 'The eternal, not ourselves, which makes for Righteousness') was a virtually universal phenomenon, one 'recognized by all civilized beings'. In the lower ranks of this Yorkshireman's anthropological hierarchy, 'even amongst the uncivilized there is a similar though narrower conception.' Balmforth (Ramsey 1889) alluded to Alexander Pope's eighteenth-century poem, 'An essay on man', in underscoring the ubiquitous character of the quest:

Lo, the poor Indian, whose untutored mind,

Sees God in clouds, or hears him in the wind.

10 Ramsey, L. 1889. 'The future development of religious life. Part I', pp. 547-550. 
After conceding the essential legitimacy of the search for higher reality, Balmforth immediately turned again on the orthodox Christian portrayal of God as a transcendent, theistic being 'with human sensibilities and powers largely magnified'. Echoing a critique made by Ludwig Feuerbach and numerous other commentators in the nineteenth century, he thought the anthropomorphic presentation of God, or projection of human attributes to the divine, was the 'cardinal defect' of Christianity and that from that infirm foundation sprang other faults of Christian orthodoxy, such as the Trinity, the Atonement, the Incarnation of God in Jesus Christ, and the inspiration of Scripture. Balmforth (Ramsey 1889) allowed that all conceptions of a Supreme Being in the human mind are perforce anthropomorphic, but he distinguished the anthropomorphism of orthodox theologians, who regarded it as essential, from that of 'the adherent of the Church of the future', for whom it was 'accidental' and employed because of an awareness of the 'inadequacy of language' in describing something that was eternal. On the basis of his acceptance of evolutionary optimism, he confidently predicted that with the ongoing development of the human intellect these 'ruder presentments' of the divine were 'bound to pass away', as had 'the barbarous conceptions of savage tribes' and other notions of it (Ramsey 1889). Linking this supposed historical truth to what he knew of Unitarianism from his experience with it in Huddersfield, while ignoring the persistence of conventional theism elsewhere, Balmforth professed that 'the 'masses' had already turned their backs on the God of the Bible and predicted that such a perception of the divine would soon be replaced by a 'wave of purified Theism' and consequently 'the Unitarian body may look for a great accession of strength.' Hedging his forecast, however, he granted that of such a development 'there are at present no great signs.' ${ }^{11}$

Although in 'The future development of religious life' Balmforth (Ramsey 1889) evinced a lack of intellectual maturity, it is nevertheless a remarkable piece and testifies not only to considerable self-acquired erudition but also to the profundity of his curiosity about religion at least four years before he undertook formal theological studies. Between its publication and his matriculation at Manchester College in Oxford, Balmforth would continue to cogitate about these matters and search for a religious faith which his post-orthodox mind could accept.

\section{PIVOTAL EMPHASES AT OXFORD}

Lines of continuity united Balmforth's late nineteenth-century ministerial training in Oxford with his efforts in South Africa late in life to predict the future of Christianity and religion generally. Beneath the Anglican veneer in Matthew Arnold's 'City of dreaming spires' with its recent legacy of the High Church Oxford Movement boiled a cauldron of theological foment, as liberal currents springing chiefly from German and Dutch sources flowed to British shores. No singular theological position

11 Ramsey, L. 1889. 'The future development of religious life. Part I', pp. 551-553. 
dominated at the University of Oxford in the late Victorian period, but whatever orthodox certainties had survived the Enlightenment were being strongly challenged. Benjamin Jowett, a distinguished Anglican classicist and New Testament scholar who had drunk deeply at the well of German Biblical criticism in the 1840 s, fought numerous battles with more conservative colleagues in Oxford for more than three decades. ${ }^{12}$ Outside the Church of England, the post-orthodox charge included some of Balmforth's Unitarian mentors. Writing retrospectively in 1935, he recalled that James Martineau, Joseph Estlin Carpenter, and James Drummond, all standing on his denomination's theologically most liberal flank, had shaped his education, though it must be noted that Martineau did not teach in Oxford, so whatever impact he made on Balmforth was probably through his publications. ${ }^{13}$ Carpenter's case is in itself illustrative in this regard. Seventeen years Balmforth's senior, he had ministered to Unitarian churches for more than a decade before being called to teach New Testament at Manchester College. However, after gaining an international reputation as a scholar in that field, he turned much of his attention to the much younger one of comparative religions, which had begun to flourish at Oxford during the third quarter of the nineteenth century. (Vide infra.)

Another sector of the theological landscape which was already in place when Balmforth arrived was the study of comparative religions. As indicated above, this had been founded especially by Müller, whose teaching career at the University of Oxford lasted from 1850 until his retirement 25 years later, but who continued to write scholarly treatises and edit Asian religious texts until the 1890s. ${ }^{14}$ The extent to which Balmforth read these works is unknown, but it seems highly plausible that during his student years he became familiar with at least some of them. Müller's controversial profile made that virtually inevitable. Especially his Gifford Lectures delivered between 1888 and 1892 in Glasgow unleashed a storm of protest. Among his many ecclesiastical detractors, Monsignor Alexander Munro of that city's Saint Andrew's Cathedral lambasted them in a curiously constructed metaphor as a 'crusade against Divine revelation, against Jesus Christ, and against Christianity'. This prominent Catholic also accused the visiting German Oxonian of proclaiming 'atheism under the guise of pantheism' to his Scottish audiences and in effect denying the existence of a personal God. ${ }^{15}$

12 Though dated, G.C. Faber, 1957, Jowett. A portrait with background, London: Faber and Faber, remains a highly useful biography which sheds much light on theological developments at Oxford during the decades immediately preceding Balmforth's studies there.

13 Balmforth, R. 1935. Jesus - the Man. London: The C.W. Daniel Company, p. 6.

14 The most detailed and reliable study of this renowned Orientalist and pioneer in the study of comparative religions is L.P. van den Bosch, 2002, Friedrich Max Müller: A life devoted to the humanities, Leiden: Brill.

15 Müller, G.A. ed. 1902. The life and letters of Right Honourable Friedrich Max Müller, Vol. II, London: Longmans, p. 263. 


\section{EXPERIENCING TRINITARIAN CHRISTIANITY IN CAPE TOWN}

As will be seen below, Balmforth's vision of a convergence of varying religious traditions obviously implied acquaintance with a broad spectrum of them. However, decades of ministry in South Africa did little to expand his theological horizons or increase his familiarity with varieties of Christianity other than his own. An awareness of this shortcoming is crucial to understanding why his prognostication shot far wide of the mark. Balmforth's failure to gain more inclusive perspectives decisively shaped his views of the future of religion, as did the heresy trial of a prominent Dutch Reformed minister and professor, Johannes du Plessis, in 1929. Upon completing his programme of studies at Manchester College in 1897, Balmforth served very briefly as the minister at the Unitarian Church in his hometown before accepting a call to what was still called the 'Free Protestant' (and not yet 'Unitarian') Church in Cape Town. As has been demonstrated elsewhere, this assembly of theologically liberal Capetonians, both English- and Afrikaans-speaking, had been gathered in the midst of ecclesiastical controversy after David Pieter Faure was refused ordination in the Dutch Reformed Church. ${ }^{16}$ Faure ministered to it while simultaneously employed in the business world until well into the 1890s. This maverick Afrikaner, who endured both physical and mental health problems for much of that decade and planned to bring down the curtain on his three decades of ministry in mid-1897, suffered a debilitating cerebral haemorrhage. Meanwhile, Balmforth, who had been advised to spend time in a milder climate in the interests of his health, hurried to the Cape as his successor at what Faure admitted in blunt terms was 'an unpopular church' ${ }^{17}$ His initial three-year contract was extended indefinitely in 1900.

Writing in 1937, Balmforth acknowledged that initially his relations with other clergymen in the Mother City had been strained or minimal. For an unspecified period after he had landed in Cape Town in June 1897, he noted, 'I was frequently cut in the streets by my fellow-ministers. ${ }^{18}$ How long such virtual ostracism lasted and the extent to which Balmforth ever interacted with counterparts in more conservative Anglophone or Dutch Reformed churches is unknown. At any rate, he did not remain totally isolated from them. A decade after his arrival, Balmforth penned a lengthy 'colonial letter' for the British Unitarian periodical The Inquirer in which he commented with unveiled gratitude that ' $\mathrm{Dr}$ [Friedrich Carl] Kolbe, the most widely known Catholic priest in South Africa, and one or two Congregational ministers, have lectured for us [in our church's Literary Society]' and that in the previous week

16 Hale, F. 2007. 'The origins of the Free Protestant Church in South Africa: David P. Faure contra Dutch Reformed Calvinism', Studia Historiae Ecclesiasticae, XXXIII(1), June 2007, pp. $327-$ 350 .

17 Faure, D.P. 1907. My life and times. Cape Town: Juta, pp. 150-152.

18 'Mr Balmforth's forty years' ministry', Free Protestant (Unitarian) Church. Monthly Calendar, XVII(6), July 1937, p. 3. 
he, apparently to his surprise, had been invited to speak 'at a meeting organised by the Evangelical Free Church Council on the Congo question - a subject upon which, some of us are trying to arouse the public conscience here'. ${ }^{19}$

However, a theological gap as great as the distance from the Jordan to the Styx continued to separate Balmforth from what he called the 'orthodox' views of most other ministers of the Gospel in South Africa. There is no evidence that during his 40 years of ministry there, he had significant contact with churches of other denominations or explored in a noteworthy way theologies which differed greatly from his own. The Barthian neo-orthodox reaction against Protestant liberalism, to cite but one obvious current which made a great impact in the Northern Hemisphere, had no perceptible impact on Balmforth. It hardly seems too much to suggest that his disparagement of most theologies prior to the unfolding of nineteenth-century liberalism as archaic and of little use to the ostensibly evolved modern mind kept him from noticing and appreciating any dimensions of them which, conceivably, he may have found enlightening. Furthermore, in addition to ministering to the spiritual needs and intellectual curiosity of his own flock in Hout Street, he wrote extensively for publication, read prodigious amounts of imaginative literature, and served on various public committees in Cape Town. Exploring a broad spectrum of current theological developments hardly seems to have been among his priorities.

On the other hand, Balmforth remained in contact with fellow Unitarians in several countries. To cite but a few examples, in 1927 he exchanged pulpits briefly with Simon Jones of High Pavement Chapel in Nottingham. ${ }^{20}$ Balmforth is also known to have corresponded with the Australian Unitarian and Free Christian Association that year. ${ }^{21}$ In 1934 he participated in a gathering of well over 300 other advocates of religious liberalism in Copenhagen; these Unitarians and others came from the Scandinavian countries, the United Kingdom, the United States of America, and other lands. ${ }^{22}$ Balmforth's cognizance of liberal trends even extended to Hinduism. He found it sufficiently important to report in his congregation's monthly periodical the centenary of the Brahmo Samaj, a major nineteenth-century reform movement in India which had spawned a separate, monotheistic religion in that country, and quoted from one of its leaders, G.Y. Chitnis, to underscore points of correspondence between it and Unitarianism. ${ }^{23}$

19 Balmforth, R. 1907. (Cape Town) to The Inquirer, 18 June 1897, in The Inquirer, no. 3397, 3 August 1907, pp. 493-494.

20 'Forthcoming exchange of Ministers', Free Protestant (Unitarian) Church. Monthly Calendar, VII(5) (March 1927), p. 4; 'Annual Meeting - Farewell to Rev. Simon Jones', Free Protestant (Unitarian) Church. Monthly Calendar, VII(11), September 1927, p. 1.

21 'Greetings from Australia', Free Protestant (Unitarian) Church. Monthly Calendar, VII(5), March 1927, p. 4.

22 'The Liberal Religious Conference at Copenhagen', Free Protestant (Unitarian) Church. Monthly Calendar, XIV(9), October 1934, p. 2.

23 Liberal religion in India', Free Protestant (Unitarian) Church. Monthly Calendar, VIII(12), November 1928, p. 4. 
This is not to suggest that the Cape Town Unitarians were entirely isolated from international Trinitarian Christianity. In March 1924, for instance, their congregation became officially affiliated with the World Alliance of Churches for Promoting International Friendship. ${ }^{24}$ But that body proved to be short-lived, and in general Unitarianism in South Africa had little meaningful contact with other branches of Christianity either in that country or abroad.

After a quarter-century of ministry in Cape Town, Balmforth was convinced that liberal religion had made noteworthy progress in South Africa. Speaking at a special anniversary service in June 1922, he declared, with regard to other Christians' reactions to Unitarianism, 'The odium theologicum and the bitterness and intolerance arising out of it had largely passed away,' supposedly because 'those responsible for such intolerance had become ashamed of their attitude.' He noted that earlier that month the Anglican bishop of Pretoria had 'adopted an attitude towards the Bible and its teachings' which he himself had preached in Cape Town since 1897. Balmforth expressed his hope that 'the new attitude towards evolution, science and ethics should find a place in the teaching of every school and college, and form part of the equipment of every teacher in the future. ${ }^{25}$

Notwithstanding his penchant for reductionist thinking which often filtered out phenomena that countered his optimistic notions about human cultural and religious evolution, Balmforth was by no means ignorant of many that clearly did. At times, however, he seems to have regarded them as mere wrinkles in the fabric, temporary roadblocks along the path of progress. Perhaps the most obvious case challenging him, one which occupied much of Balmforth's attention in the late 1920s, was the heresy trial of Du Plessis. This highly publicised event must have seemed to put under ecclesiastical indictment much for which the transplanted English Unitarian himself stood for, albeit to a greater degree than the liberal Dutch Reformed dominee. That the trial could even take place Balmforth regarded as 'simply pitiful' and 'an exhibition of obscurantism and idolatry'. The accusations against Du Plessis, he thought, revealed 'how crude and lax has been the religious education of our South African people, Dutch, English, and German alike', all of whom had apparently been left behind while liberal religious enlightenment had surged ahead in the lands of their forefathers. ${ }^{26}$ So incensed was Balmforth at this ostensible backwardness that he preached a brief series of sermons about the trial and its ramifications in October 1929. ${ }^{27}$ In one of these orations, he dismissed the trial in Stellenbosch as a grand anachronism, a spectacle, admittedly one 'in a milder and minor variation of the

24 Untitled notice, Free Protestant (Unitarian) Church. Monthly Calendar, V(2), September 1924, p. 2.

25 'News of the Churches. Cape Town', The Inquirer, no. 4178, 29 July 1922, p. 489.

26 Balmforth, R. 1929a. 'The heresy trial at Stellenbosch', Free Protestant (Unitarian) Church. Monthly Calendar, IX(10), October 1929, p. 2.

27 'Services during October', Free Protestant (Unitarian) Church. Monthly Calendar, IX(10), October 1929, p. 1. 
same spirit', which re-enacted the torturing and burning of heretics in the Middle Ages. ${ }^{28}$

\section{'MODERNISM AND THE RELIGION OF THE FUTURE'}

Thirty-two years after landing in Cape Town, Balmforth (1929c), then 68 years old, contributed to the South African periodical The Outspan a lengthy article in which he outlined his vision of the future trajectory of nota bene 'religion', not merely Christianity. Much of what he wrote in that piece was hardly novel in his scholarly production; Balmforth had foreshadowed it in series of 'discourses' delivered in his church on Sunday evenings. Other aspects anticipated lectures he would deliver within approximately a year. In the late 1920 s, for example, Balmforth preached a series of 'sermons' (as they were announced) with such titles as 'Modernism as a world movement', 'The spiritual basis of modernism', 'Modernism and the Bible', and 'Modernism and miracles' ${ }^{29}$ In April, May, and June 1930, moreover, he continued his exploration of faiths outside Christianity with a series titled 'Seven great religions'. In these far-ranging discourses Balmforth discussed 'Confucianism'; 'Hinduism'; 'Buddhism'; 'Zoroastrianism'; 'Mohammedanism'; 'Judaism'; and 'Christianity - and its relation to other Religions' ${ }^{30}$ His comments from the pulpit about comparative religion remain unpublished, and no manuscripts of them appear to be extant. However, the very fact that Balmforth (who regarded the message of Jesus as only part, albeit a highly significant one, of the broad revelation of divine truth through intellectual culture), delved deeply into this field underscores not only his tolerance of other religions but also his belief that they should be respected as channels of truth. That was a vital dimension of his modernist attitude which informed his view of what not merely Christianity but 'the religion of the future' would include.

Balmforth postulated much of his argument about the future of religion on his unshakable conviction that Darwinian evolution was no longer a theory to be debated but a proven fact of life to be accepted with gratitude. The timing of his own existence could hardly have been more auspicious in this regard. Two years before his birth, Darwin had finally published many of his findings as On the origin of species by natural selection. To be sure, it was not initially met with universal acclaim. Indeed, for many years natural scientists continued to discuss the strengths and weaknesses of his theory. His volume of 1871, The descent of man, and Selection in relation to sex, added fuel to the fire, not least in ecclesiastical circles. However, Darwinism

28 Balmforth, R. 1929b. 'The heresy trial at Stellenbosch', Free Protestant (Unitarian) Church. Monthly Calendar, IX(11), November 1929, p. 2.

29 'Church Services', Free Protestant (Unitarian) Church. Monthly Calendar, IX(4), April 1929, p. 2.

30 'Church Services', Free Protestant (Unitarian) Church. Monthly Calendar, X(3), April 1930, p. 2. 
gained steadily more footholds in British and continental European academic life, and by the time Balmforth proceeded to Oxford it had been very widely accepted and made its impact felt on not only on the natural sciences but in other fields of knowledge, as well.

When Balmforth built his case in 1929 on a Darwinian foundation, he was continuing a central theme in his literary output, one which had permeated much of what he had published over a period of several decades beginning well before his emigration from England. Balmforth's essay 'The influence of the Darwinian theory on ethics', to cite one key example, was published in the International Journal of Ethics in 1911, but he had previously delivered it as an address to the South African Association for the Advancement of Science, and several paragraphs from previous works were incorporated in the text. Balmforth could speak with unabashed exaggeration about 'the almost universal acceptance of the Darwinian theory of evolution' without, apparently, realising that large numbers of Christian theologians, clergymen, and lay people in the United Kingdom, South Africa, and the United States of America, among other countries, had categorically rejected it. Projecting his own Weltanschauung and that of many like-minded people to entire populations, he declared broadly:

We think and speak in terms of evolution, and the theory has so far permeated all our thinking that not only biological science, but ethics, economics, and social and political theories and institutions, are beginning to feel the influence of the new ideals and methods of thought which the theory has brought with it (Balmforth 1911).

Balmforth granted that initially unspecified 'theological extremists had proclaimed "horror-stricken anathemas", but he believed that after half a century a consensus had emerged regarding the clear gain which has come to humanity', not least with regard to 'ethical study'. Indeed, it seemed to the optimistic strain in his pre-1914 mind that 'ethical advance has become clearer and surer.' That 'evils' continued to 'surround us' was a fact 'too palpable to be ignored'; nevertheless, he assured his audience and readers that 'this upward life-tendency, which is everywhere observable in nature, cannot be ignored either,' and because the general course of nature was one of ascent, 'our way is upward too.' 31

In the introductory section of his key article of 1929, Balmforth (1929c) nailed his evolutionary colours to the mast. He began by quoting Jowett approvingly: 'No religion can long endure...if it is out of harmony with the best thought and science of the time.' In his own day, Balmforth professed, the faith of modernism was the fulfilment of this, as it sought to harmonise 'the discoveries of science, the findings of the higher criticism and the science of comparative religion, and the conclusions of philosophy' (Balmforth 1929c). He dwelt almost fawningly on

31 Balmforth, R. 1911. 'The influence of the Darwinian theory on ethics', International Journal of Ethics, XXI(4), July 1911, pp. 448-449, 455. 
Darwinian evolution and its ramifications beyond the natural sciences to enlighten mankind's comprehension of 'every department of thought and life'. Its value could hardly have been more comprehensive. To the grateful Balmforth, it seemed that evolutionary thinking was revealing the trajectories of not only 'stars, and suns, and systems, but of every form of life upon the earth, including the life of man, and all the institutions, literatures, bibles, churches, creeds, societies, industries, and forms of government which spring out of human life' (Balmforth 1929c). Balmforth's pointed inclusion of 'bibles, churches, [and] creeds' in his catalogue of evolving phenomena highlights his conviction that Christianity was not a static, final revolution of divine truth. Moreover, this mirrored what he had discussed at great length in a series of 'discourses' delivered shortly after taking up his ministry in Cape Town in 1897 and subsequently published as a 165-page book in London titled The revelation of Christianity. ${ }^{32}$ In brief, they comprised a historical survey of the faith from the apostolic age until the Enlightenment, emphasising the increasing role of human reason and, concomitantly, the detachment of Christian life and thought from what Balmforth regarded as archaic and authoritarian thinking and institutions, not the least of which was the Roman Catholic Church.

In support of his unswerving conviction that religion and Darwinian evolution were compatible, Balmforth marshalled two high-ranking Anglican clerics. The first was the long-term bishop of Birmingham, Ernest William Barnes, who had been educated in mathematics and natural sciences at the University of Cambridge before entering the ministry. Balmforth urged readers to take up Barnes's (1927) Should such a faith offend? What he did not mention, however, was that owing chiefly to his very liberal theological positions, Barnes had aroused staunch opposition in the Church of England, hostility which would continue throughout the three decades of his episcopal tenure. But his commitment to evolutionary thinking, eugenics, and pacifism harmonised well enough with Balmforth's own opinions, allowing Barnes to serve rhetorically as an unwitting ally. The second was Neville Stuart Talbot, the bishop of Pretoria during the 1920s. Balmforth recommended his A Biblical thoroughfare (Talbot 1928), which had been published by the Student Christian Movement in London as an endeavour to familiarise the public with many recent findings of Old and New Testament scholarship. ${ }^{33}$

In the historiography of European theology, the First World War of 1914-1918 is often regarded as having sounded the death-knell for liberal Protestant theology. According to this general interpretation, years of carnage on the battlefields in France and elsewhere graphically proved the unviability of the optimism which had undergirded liberal perceptions of human nature. Challenged, if not entirely destroyed, was the trust in the progressive view which emphasised the brotherhood of mankind and believed that human society was generally advancing towards

32 Balmforth, R. 1898. The evolution of Christianity. London: Swan Sonnenschein.

33 Balmforth, R. 1929. 'Modernism and the religion of the future'..., p. 59. 
general harmony. Less than a year after the armistice of November 1918, Karl Barth published his seminal Der Römerbrief, in which he reminded fellow Protestants that their abiding luminaries who pointed to the truth of the Gospel were not nineteenthcentury liberals like Friedrich Schleiermacher, but giants of the Reformation like Martin Luther and John Calvin who had pointed to the moral and spiritual depravity of our species and insisted that our salvation thus depended solely on God's grace.

Writing a decade after Barth had sprung into prominence, however, Balmforth clung tenaciously to his modernist precepts and indeed insisted that the Great War had precipitated a 'spiritual cataclysm' in which the faith of 'millions crumbled into ruin'. But instead of commenting on how the vicious war as such, where men suffered 'under conditions as terrible as any of the cruellest human sacrifices of ancient times', had run counter to liberal assumptions about human nature, he concentrated on how in the midst of it religious leaders, both Christian and nonChristian, had responded in non-doctrinal ways to alleviate the misery. He found it gratifying that 'Catholic priests, Protestant clergymen, Nonconformist ministers, Jewish rabbis, Mohammedan imaums [sic], [and] Hindu priests, [were] ministering to sorely wounded men in their last hours of darkness and unspeakable pain, without asking, without caring, what faith they professed...' (Balmforth 1929). Balmforth appealed to the mythic 'impartial reader' to juxtapose the tolerant and co-operative tenor of such military chaplaincy with what he termed "the narrow spirit which would limit religion and the possibilities of salvation to those who hold the "correct" doctrines and theories about Jesus Christ - doctrines and theories of which Jesus himself never heard...'. When such a contrast was made, Balmforth asserted, one would 'realise how the great world of humanity is drifting slowly past the dry bones of creed-and-ritual-bound religions, how it is hungering and searching for higher and better things, and moving on towards them'.$^{34}$

Did Balmforth actually believe that a homogenisation of religious beliefs and traditions was underway? There is little reason to doubt it. On the one hand, he had just witnessed what he described as a reactionary and intolerant stance among conservative Dutch Reformed compatriots against Du Plessis, but that he apparently could dismiss as a local aberration from broader ecumenical trends on the international stage. His congregation's affiliation with the new World Alliance of Churches five years previously was one such development which he thought overshadowed the machinations of local Afrikaners against a liberal theologian in their ranks. That international body, Balmforth incautiously assured readers, showed the way forward because it 'does not lay down any dogmatic ecclesiastical or theological creed as a condition of membership, but only asks the co-operation of all who will pledge themselves to work for the peace and fellowship of mankind' (Balmforth 1929). It heartened him that 'even so-called heretical churches are admitted to that organisation.' Extending the latitude still further, he announced with unveiled glee

34 Balmforth, R. 1929. 'Modernism and the religion of the future'..., p. 43. 
that in 1930 an even more inclusive body, 'embracing not only Christian churches, but also the non-Christian religions of the East, will meet at Geneva to work together for the same end - the unifying and co-ordinating of the religious thought of the world in the direction of international co-operation' ${ }^{35}$

\section{CONCLUSION: HOW BALMFORTH'S PROGNOSTICATIONS WENT ASTRAY}

How could a man of Balmforth's intellectual capacity have missed the target by such a wide margin? In brief, the answer apparently lies primarily in his myopic failure to see, let alone come to grips with, the vitality of conventional varieties of Christianity which, in general, did not dovetail with his view of what religion in the twentieth century should be. For all his ostensibly cosmopolitan outlook, he had been living in relative isolation from those large and enduring genuses of the faith and concentrated his attention chiefly on the narrow segment which Unitarianism and other liberal varieties represented. To be sure, Balmforth occasionally referred respectfully to Anglican and other churchmen in his Sunday evening 'discourses' and in his writing, and even to the prominent local Catholic priest Kolbe whose denominational heritage he found abominable. However, at no time in his life is Balmforth known to have had much meaningful involvement with churches other than those which identified themselves as Unitarian, and in South Africa that was almost exclusively his own congregation in Cape Town. Furthermore, he was so convinced that modernist theology meshed with the sacred truths of evolutionary thinking that he does not appear ever to have stood back from his extreme liberalism to evaluate its weaknesses, including its dependency on an elevated view of rationalism and human perfectibility. A decade after Balmsforth (1929c) wrote 'Modernism and the religion of the future', the Second World War erupted in Europe, the culmination of what must have been an increasingly disillusioning decade for optimists like himself. Foresaging that, upon returning to Cape Town after attending the 1934 conference of religious liberals in Copenhagen he reported that dark days lay ahead. A 'reactionary movement' was snowballing 'everywhere in the world'. $\mathrm{He}$ predicted that 'dictatorships, the spirit of violence and intolerance, and superstitious forms of religion, along with a gross and selfish materialism, were gathering strength everywhere,' and 'for years to come' religious liberals would be compelled to fight in defence of those religious principles' for which they stood..$^{36}$ Those words, written slightly more than a quinquennium after Balmforth's endlessly optimistic essay had appeared in print, pointed in an almost diametrically opposite direction.

35 Balmforth, R. 1929. 'Modernism and the religion of the future'..., p. 59.

36 'Welcome home to the Rev. R. and Mrs Balmforth', Free Protestant (Unitarian) Church. Monthly Calendar, XIV(10), November 1934, p. 4. 
In South Africa, the history of the churches during the decades between the two world wars cannot be said to have been characterised by a jettisoning of creeds or doctrinal distinctives. Much the same can be said of Christianity in Balmforth's native England. And when one turns to the history of Christianity in the United States of America, one finds strong reactions in the 1920s against theological modernism, movements which gave rise to the terms 'fundamentalism' and 'fundamentalist' in the early 1920s. Finally, the history of the Roman Catholic Church during the past century, despite considerable outreach to other denominations (or 'ecclesial communities', in the parlance of the Second Vatican Council) makes Balmforth's bold prognostications about Christianity in general surrendering unique doctrines and merging with other religions risible. In short, by concentrating his gaze almost exclusively on developments which confirmed his own views, he overlooked many which countered them.

But surely the most appalling and myopic aspect of Balmforth's vision of the future of religion, especially considering that he viewed the subject from a South African perspective and published his prognostication in one of the country's periodicals, was his failure to take into account the extent and accelerating growth of Christianity among its indigenous ethnic groups. By the late 1920s many decades of intensive missionary endeavours throughout much of the Union of South Africa and its antecedent lands had brought that faith to millions of people, a considerable proportion of whom had responded by becoming Christians. The numbers of African Anglicans, Lutherans, Catholics, Baptists, Presbyterians, Methodists, and, not least, adherents of the rapidly expanding 'independent churches' dwarfed - to say the least - those Christians whose beliefs can be assumed to have harmonised with Balmforth's. Owing in large measure to the arrival of the Apostolic Faith Mission, the Pentecostal movement had been proliferating across much of the ethnic rainbow in South Africa for approximately two decades. Moreover, the Xhosa and other black population groups of the Western Cape were already considerable when he declared without qualification that theological modernism pointed to the future of the faith. Far larger, to be sure, in the region that this transplanted Yorkshireman had called home for more than three decades were the Coloured churches of various denominational hues. One can only wonder what he would have predicted their religious life would be like down the road. His argument provides no clues whatsoever; its narrowly defined scope did not in any way extend to these massive components of the regional or national population.

\section{LIST OF REFERENCES}

Balmforth, R. 1898. The evolution of Christianity. London: Swan Sonnenschein.

Balmforth, R. 1907. (Cape Town) to The Inquirer, 18 June 1897, in The Inquirer, no. 3397, 3 August 1907, pp. 493-494. 
Balmforth, R. 1911. 'The Influence of the Darwinian theory on ethics', International Journal of Ethics, XXI(4), July 1911, pp. 448-465.

Balmforth, R.1929a. 'The heresy trial at Stellenbosch', Free Protestant (Unitarian) Church. Monthly Calendar, IX(10), October 1929, pp. 2-3.

Balmforth, R. 1929b. 'The heresy trial at Stellenbosch', Free Protestant (Unitarian) Church. Monthly Calendar, IX(11), November 1929, p. 2.

Balmforth, R. 1929c. 'Modernism and the religion of the future', The Outspan, V(118), 31 May 1929, pp. 43-44.

Balmforth, R. 1935. Jesus - the Man. London: The C.W. Daniel Company.

Balmforth, R. (n.d.). Unpublished memoirs. Bridget Stoddart private archives, Fish Hoek, South Africa.

Barnes, E.W. 1927. Should such a faith offend? Sermons and addresses. London: Hodder and Stoughton.

Berman, D. 1990. A history of atheism in Britain: From Hobbes to Russell. London: Routledge.

Faber, G.C. 1957. Jowett. A portrait with background. London: Faber and Faber.

Faure, D.P.1907. My life and times. Cape Town: Juta.

Hale, F. 2007. 'The origins of the Free Protestant Church in South Africa: David P. Faure contra Dutch Reformed Calvinism', Studia Historiae Ecclesiasticae, XXXIII(1), June 2007, pp. 327-350.

Hale, F. 2013. 'Victorian Biblical scholarship in twentieth-century South Africa: Ramsden Balmforth's advocacy of higher criticism', Studia Historiae Ecclesiasticae, XXXIX, Supplement, August 2013, pp. 365-383.

Müller, F.M. 1894. Chips from a German workshop. 4 volumes. N.p.: Longmans, Green.

Müller, G.A. ed. 1902. The life and letters of the Right Hon. Friedrich Max Müller. 2 volumes. London: Longmans, Green.

Niblett, B. 2011. Dare to stand alone: The story of Charles Bradlaugh. Oxford: Kramedart Press.

Ramsey, L. 1889. 'The future development of religious life. Part I', The Westminster Review, CXXXI(6), May 1889, pp. 545-546.

Royle, E. 1974. Victorian infidels: The origins of the British Secularist Movement, 1791-1866. Manchester University Press.

Royle, E. 1980. Radicals, secularists and republicans: Popular freethought in Britain, 1866-1915. Manchester University Press.

Talbot, N.S. 1928. A Biblical thoroughfare; or, an endeavour to share the main results of Biblical scholarship with the general public. London: Student Christian Movement.

Van den Bosch, L.P. 2002. Friedrich Max Müller: A life devoted to the humanities. Leiden: Brill.

\section{Newspaper sources:}

'Cape Town Jubilee', The Inquirer, no. 4,435, 2 July 1927, Supplement, p. ii.

'Intrepid liberal' (editorial), The Forum, IV(41), 10 January 1942, p. 5.

'News of the Churches. Cape Town', The Inquirer, no. 4178, 29 July 1922, p. 489. 


\section{List of references from the Free Protestant (Unitarian) Church communications}

(Listed in order of footnote references)

\#18: 'Mr Balmforth's forty years' ministry', Free Protestant (Unitarian) Church. Monthly Calendar, XVII(6), July 1937, pp. 3-4.

\#20: 'Forthcoming exchange of Ministers', Free Protestant (Unitarian) Church. Monthly Calendar, VII(5) (March 1927), p. 4; 'Annual Meeting - Farewell to Rev. Simon Jones', Free Protestant (Unitarian) Church. Monthly Calendar, VII(11), September 1927, p. 1.

\#21: 'Greetings from Australia', Free Protestant (Unitarian) Church. Monthly Calendar, VII(5), March 1927, p. 4.

\#22: 'The Liberal Religious Conference at Copenhagen', Free Protestant (Unitarian) Church. Monthly Calendar, XIV(9), October 1934, p. 2.

\#23: 'Liberal religion in India', Free Protestant (Unitarian) Church. Monthly Calendar, VIII(12), November 1928, p. 4.

\#24: Untitled notice, Free Protestant (Unitarian) Church. Monthly Calendar, V(2), September 1924, p. 2.

\#27: 'Services during October', Free Protestant (Unitarian) Church. Monthly Calendar, IX(10), October 1929, p. 1.

\#29: 'Church Services', Free Protestant (Unitarian) Church. Monthly Calendar, IX(4), April 1929 , p. 2

\#30: 'Church Services', Free Protestant (Unitarian) Church. Monthly Calendar, X(3), April 1930, p. 2.

\#36: 'Welcome home to the Rev. R. and Mrs Balmforth', Free Protestant (Unitarian) Church. Monthly Calendar, XIV(10), November 1934, p. 4. 